\title{
A Short Article on the Superiority of Women
}

Gynecology and Women's Health Care

Short Communication

\begin{tabular}{ll}
\hline Dr. James F Welles \\
Submitted & : January $22^{\text {nd }}, 2020$ \\
Accepted & : January $28^{\text {th }}, 2020$ \\
Published & : February $1^{\text {st }}, 2020$
\end{tabular}

Correspondence author

Dr. James F Welles

Ph.D

P. O. Box 17

East Marion

New York

11939

USA

Tel : 954-531-5382

E-mail :jwelles103@aol.com

Women have been universally and eternally victimized by stereotyping 1 to the degree that 400 years ago, no less of an expert on females than Cardinal de Richelieu concluded that "Intellect in a woman is unbecoming" [1, 2].

It is alleged that the female psyche has somehow been permanently shaped by the oft-noted ability of women to bear children. It may well be that there is something to this a for mothers (who still do usually tend to be female) who spend more than 24 hours a day in the presence of children. Anyone subjected to such a situation might have to sacrifice something to emotional stability, and it may be a bit of logic and sanity. Recent research indicates there are real differences between male and female brains, 3 so there may well be a special brand of feminine stupidity. However, before we venture too far into the unchartered domain of comparative idiocy, let us indulge in a bit of diplomacy and allow that the two sexes are, in their own aggravating ways, equally stupid or at least appear to be so to the advocates of the presumably equal other. That said, we must allow the "Duh moment" usually goes to a thickheaded male-is there any other kind?--who come to a belated realization when he informs the woman he has been living with for X years he is moving out bursts into tears. On the other hand, garrulous women have difficulty saying, "I love you" in the language of their choice: they show it but cannot say it.

Be that as it may, women make better police people, doctors, drivers, gamblers, spies, world leaders, beer tasters, hedge fund managers and just about everything else-e.g., mothers-than men.4 It is in fact difficult to find something in which men excel other than $400 \mathrm{lb}$. bench presses. The inferiority of women in matters of physical strength when human culture was beginning apparently led males to slight them in all other respects up to now.

As psychologist, Justin Timberlake observed when reflecting on his fling with Cameron Diaz: “I learnt a lot...but I'm still a man, so I have some kind of learning disability."

As an inducer of stupidity, sex narrows the focus of those involved to a single-minded pursuit of self-gratification, so on this one let us give an edge to men [3]. Clearly, the institution of marriage is a miserable failure in serving the sex urges of overwhelming numbers of people-especially single males and spouses. (Everleigh sisters.) Marriage should be a child rearing but not necessarily sexual institution. Marry for children but, like the ancient Greeks stay open on sex and sex partners: Forsaking most others Should be enough and usually is.* Btw is it not odd that free sex is legal, but prostitution is a crime? Sex is the only thing for which one cannot charge but can give away. [During prohibition, the manufacture, transportation or sale of alcohol was illegal but one could give it away or buy it and drink it.] *As Benny Franklin advised, "Keep your eyes open before marriage and halfclosed afterwards [4].

One of the lesser known reform organization was the Female Retrenchment Society, which defended women against the temptations of tea, coffee, rich cake, pastry, preserves, snuff and tobacco as well as wine and cordials.

are scarce [4]. 


\section{References}

1. Hammond P (1978) an Introduction to Cultural and Social Anthropology. 2nd ed. Macmillan; New York 185.

2. Richelieu A de. Circa 1630. Quoted by Richard Nixon on p. 106 of Living History by H. Clinton. Simon and Schuster; New York. 2003

3. Johnson S (2004) Mind Wide Open. Scribner; NY 14.

4. Abrams D, Man Down (2011) Posted by K. Madden. AOL. Throw in phone operators. The buzz immediately after D-Day was that we could be thrown off the beach unless we got some women on shore pronto to operate the phone system. Maybe men are more logical, but women are definitely better at dealing with chaos and all kinds of crazy things happening at once. Ditto surgeons: Albeit anecdotal, someone who observed the work of women surgeons commented. "It is amazing anyone let men be surgeons". 